Please do not remove this page

RMIT

UNIVERSITY

\title{
A collective, undifferentiated accounting profession: an Australian study
}

Inglis, Robert; Shelly, Marita; Morley, Clive; De Lange, Paul

https://researchrepository.rmit.edu.au/esploro/outputs/9921858337601341/filesAndLinks?institution=61RMIT_INST\&index=null

Inglis, R., Shelly, M., Morley, C., \& De Lange, P. (2011). A collective, undifferentiated accounting profession: an Australian study. Accounting and Finance, 51(3), 711-731.

https://doi.org/10.1111/j.1467-629X.2011.00429.x

Document Version: Published Version

Published Version: https://doi.org/10.1111/j.1467-629X.2011.00429.x

Repository homepage: https://researchrepository.rmit.edu.au (c) 2011 The Authors, Accounting and Finance (c) 2011 AFAANZ

Downloaded On 2023/04/26 23:01:15 +1000 


\title{
A collective, undifferentiated accounting profession: An Australian study
}

\author{
Robert Inglis \\ School of Accounting \\ RMIT University \\ Marita Shelly \\ School of Accounting \\ RMIT University \\ Clive Morley \\ Graduate School of Business and Law \\ RMIT University \\ Paul De Lange ${ }^{1}$ \\ School of Accounting \\ RMIT University
}

Journal of Economic Literature classification: 121

Key words: Accounting, Professional accounting bodies, brand, membership, differentiation

1 Corresponding Author: Paul DeLange, School of Accounting RMIT University, Level 15239 Bourke Street, Melbourne VIC 3000, Telephone: 03 9925 5715 , Fax: 03 9925 5741, email: paul.delange@rmit.edu.au.

Acknowledgment: The authors would like to thank CPA Australia for their generosity in providing financial assistance for this research. Our appreciation is also extended to Peter Clarkson, deputy editor Accounting and Finance and the anonymous referees for their constructive comments on earlier versions of this paper. 


\title{
A collective, undifferentiated accounting profession: An Australian study
}

\begin{abstract}
A study of 386 potential and current members of the accounting profession in Australia and South-East Asia provides evidence of the importance of three attributes - brand/reputation, international recognition of qualifications and career opportunities - in the decision to join a professional accounting body. While these attributes are important, logit regression models indicate that they are not discriminatory in the choice of professional body and suggest a perception of a collective, undifferentiated, accountancy profession. The marketing of brand/reputation and membership benefits may be a more efficient and effective strategy in attracting members and differentiating the profession if undertaken by a combined or coordinated professional body.
\end{abstract}




\section{Introduction and background}

Professional accounting bodies continue to face on-going challenges in the recruitment and retention of accounting graduates (Albrecht and Sack, 2000; Tan and Laswad, 2006) and in responding to changes in the socio-politico-economic environment (Parker, 2001). Related to environmental changes are increased competition within the accounting profession for traditional reporting and audit services, the broadening of accounting-related services and the emergence of non-accounting regulated competitors (Velayutham, 1999/2000; Sauser, 2000; Parker, 2001). While providing greater work opportunities for the accounting profession, the broadening market for accounting-related services also provides an alternative career path for potential and existing members of the profession who could avail themselves of "other groups of professionals” seeking graduates with a broader-based skill set (Parker, 2001, p. 434).

In response to these member and competitive challenges, professional accounting bodies have sought to actively and strategically differentiate themselves in the market for accounting services. The means of competitively differentiating the accounting profession in Australia has been primarily through the promotion of distinct brands such as CPA and CA (Parker, 2005) and an emphasis on the reputation for quality and expertise of professional accounting qualifications. Velayutham and Rahman (2000) highlight the marketing of brand image as a way of differentiating professional accounting services from other non-accounting regulated service providers and creating value for members of the professional accounting bodies. Member value, in this instance, is created by communicating important information about the profession and professional accounting services and potentially attracting new members to, and retaining current members within, the accounting profession. In a sense, the branding strategy has sought to position the accounting profession as one which offers attractive career opportunities and benefits to members while concomitantly differentiating the profession in the competitive market for accounting services. Consistent with this brand positioning of a 
"value-adding” profession, accounting bodies in Australia have instituted changes to the educational components of their graduate professional programs to develop a broad-based knowledge and skill set among members. Graduate programs, such as the CA and CPA programs offered by the Institute of Chartered Accountants in Australia and CPA Australia respectively, place increased emphasise on strategic and international issues and the role of accountants. Membership entrance requirements have also been broadened to encourage the entry of graduates from diverse backgrounds and with a range of abilities (The Institute of Chartered Accountants in Australia and CPA Australia, 2009, p iii).

While brand image and professional qualifications are the most overt features of the profession, there is relatively little extant research which evidences the importance or significance of these features in differentiating between professional accounting bodies in Australia. There is also limited evidence on whether brand, professional qualifications or other attributes are influential in the decision to join a professional accounting body.

Accordingly, this paper reports the findings of a study that sought to examine the importance of brand and qualifications amongst a range of potential attributes in distinguishing between professional accounting bodies and in influencing the potential decision to join a particular professional accounting body (see appendix 1 for a brief description of each accounting body reported in this study). The focus of this research is on the views of potential and current members. Two groups of accounting students were surveyed: those who were currently studying their final year in a Bachelor of Business (Accounting) degree - potential members of the profession - and recent graduates (alumni) of a Bachelor of Business (Accounting) degree - likely members of the profession.

In the next section, the theoretical framework for the paper is outlined. This is followed in section three by a description of the research method including a discussion of the population samples, questionnaire development and data collection. The data analysis and results are then 
presented in section four. The paper concludes with a discussion of the findings and suggestions for further research.

\section{Theoretical framework}

In considering the theoretical framework for this paper we have reviewed and gained insights from broad-level research into accounting as a career choice (given the perceived evolution of the accounting profession to a market-driven and differentiated form (Velayutham and Rahman, 2000; Parker, 2001)) and economic models drawn from consumer decision theory.

The accounting career-choice literature is an important source of information about those attributes that attract individuals to the discipline of accounting. From a review of the careerchoice literature, Simons et al. (2004) conclude that the findings from both theory, such as those based on theories of reasoned action (Felton et al., 1995), and non-theory based studies are 'quite similar' in the factors of most importance in influencing the decision to pursue accounting. Earnings and career opportunities, or what Tan and Laswad (2006, p. 169) describe as 'market related factors', are consistently identified in research findings (see, for example, Paolillo and Estes, 1982; Mauldin et al., 2000; Chen et al., 2008) as of most significance in influencing the choice of accounting as a career.

Simons et al. (2004) suggest that theoretical models based upon consumer decision-theory, prevalent within the marketing discipline, offer a relevant, but relatively untested, framework in examining career-choice in accounting. In consumer decision-theory, the decision choice is influenced by the importance afforded by the consumer to the perceived benefits and perceived costs in acquiring a service or product. A benefits cost approach has intuitive appeal in researching accounting and has been adopted in a number of studies of accounting as a career choice (Felton et al., 1995; Chen et al., 2008). In the seminal works of Lancaster (1966, 
1971) on consumer theory, benefits were considered to be derived not from the product itself but from the 'attributes' or 'characteristics' which they provide to the consumer. Attributes of importance for members of professional accounting bodies might encompass the prospect of greater earnings potential and employment opportunities, internationally recognised qualifications and access to professional support while costs might include joining and ongoing membership costs and the time involved in meeting professional qualification and ongoing professional development.

An understanding of attributes is of significant importance for the accounting profession and professional accounting bodies as a variation in the composition of attributes provides a primary means of differentiation (Forbis and Mehta, 1981; Porter, 1985; Day and Wensley, 1988).

Studies of the evolution and future of the accounting profession have highlighted a shift in the scope and nature of accounting work, the emergence of non-accounting competitors and a strategic (responsive) move by professional accounting bodies to differentiate through branding (Velayutham and Rahman, 2000; Parker, 2001; Parker, 2005; Richardson and Jones, 2007). The CPA and CA brands and brand marketing, for example, are perceived as mechanisms for developing and communicating the reputation of the professional body and its members, providing information about the quality and market-oriented nature of accounting services and highlighting the value of professional membership (Richardson, 1997; Velayutham, 1999/2000; Parker, 2005). Brand and reputation reflect key attributes of an evolving competitive accounting profession. In this study, we are particularly interested in how, if at all, these attributes differentiate professional accounting bodies in the opinion of potential and current members.

In drawing upon consumer decision-theory to inform the design and analysis of this research, we examine two main research questions: 
RQ1: What attributes are most important for potential members in differentiating between professional accounting bodies?

RQ2: Does brand and reputation influence the choice of a particular professional body for potential members?

Consumer decision-theory also suggests that demographic attributes of the "consumer" are possible sources of differentiation. These demographic attributes have, in previous studies of accounting career-choice, generally been encompassed in the reporting of research results as a homogeneous population. Simons et al. (2004) identify gender as one particular example in which decision criteria may differ and raise the possibility of other identifiable characteristics. In addition to gender, we investigate the potentially differentiating attributes of age, employment status, mode of study - full- or part-time - and the geographical location country of origin - of accounting education.

\section{Research method}

The major instrument for this study was a questionnaire survey of two student cohorts. The first cohort comprised 275 full- and part-time students who were studying (current students) their final year of a Bachelor of Business (Accounting) degree offered by a major university in Australia and delivered in 4 geographic campus locations - Melbourne, Singapore, Hong Kong and Malaysia. The second cohort comprised 111 alumni (past students) of the same university who had completed on a part-time or full-time basis their Bachelor of Business (Accountancy) degree in 2004 and 2005. The Bachelor of Business (Accountancy) degree is a 4-year full-time (including a $3^{\text {rd }}$ year work experience component) or 6-year part-time program specifically designed to meet the academic entry requirements to professional accounting bodies both in Australia and overseas. By concentrating on those who were currently 
considering, or have most recently chosen, accounting as a profession, key attributes differentiating the choice of professional affiliation might be more readily revealed. The data were analysed by means of logit regression models estimated for each choice of accountancy body - considered an appropriate and robust technique to test the attributes impacting on such discrete choices.

\subsection{Questionnaire development}

The questionnaire was composed of two sections (see appendix 2 for the survey instrument). Section A of the questionnaire sought respondent information on a range of attributes of importance in differentiating and influencing the choice of affiliation of a professional accounting body. Given the objective to explore potentially differentiating attributes across a number of South-East Asian (SE Asian) locations, a list of professional accounting bodies was identified from publicly available sources (e.g., media publications and web-sites) and provision made for respondents to identify other accountancy bodies of which they were, or intended to become, a member.

Respondents were asked to indicate attribute importance on a five-point scale of 1 (not important) to 5 (very important). Attributes were drawn from the findings of studies in accounting career-choice, such as earnings (salary) and career opportunities, and from studies of the evolution of the accounting profession, such as brand and reputation of professional accounting qualifications. Attributes were also identified from informational sources such as web-sites, and marketing materials provided to the public by professional accounting bodies (e.g. CPA Australia, Institute of Chartered Accountants in Australia, Association of Chartered Certified Accountants). This information media consistently identified a range of benefits and costs of being a member, including the international recognition of a professional affiliation, the costs and requirements to join and on-going costs to maintain professional affiliation. 
The research instrument was carefully designed to capture as many attributes as possible while ensuring that the practical aspects of completing the questionnaire in a relatively short time-frame were not compromised. The questionnaire was first piloted with a group of accounting academics all of whom were, or had been, members of a professional accounting body and who had experience in accounting education in the SE Asian campuses at which the survey was to be undertaken. Based on feedback from academics, the questionnaire was further refined and then piloted with a group of current students and alumni to elicit further comment. Permanent residency, for example, was one attribute that was added based on feedback from academics and students and was in accord with the findings of studies on international students studying accounting in Australia (Jackling, 2007; Birrell and Healy, 2008). The feedback loops helped refine the final instrument and, in all, 13 'importance attributes' drawn equally from the literature and other materials were identified:

- financial cost to join

- on-going membership costs

- professional education requirements

- reputation/brand of the professional accounting body

- membership benefits e.g., online library/research facilities, newsletters, continuing professional development

- enhancing career opportunities

- international recognition

- perceived expertise of the professional accounting body e.g., associated with large public accounting focus versus broad industry focus

- $\quad$ salary of members of the accounting body

- employer paying membership fees

- potential/place of work 
- $\quad$ ease of becoming a member; entry requirements

- $\quad$ assistance in gaining permanent residency

Provision was also made for respondents to identify and rate other attributes of importance.

Section B of the questionnaire sought demographic attribute information such as gender, age, mode of study, campus location, employment status and area of employment. Provision for additional comments by respondents was also included in this section.

\subsection{Data collection}

The questionnaire was administered by staff unconnected to the research team and completed by students in their regular classes in the second semester of 2006 at all four campuses. The questionnaire was also mailed to alumni over a period of four months from August to November 2006 with a follow-up email reminder sent at the end of the second month. Instructions accompanying the questionnaire identified the purpose of the survey as gathering information pertaining to choice of professional accounting bodies and emphasised aspects of confidentially and anonymity of response. Table 1 provides details of demographic attributes of the respondents for current students and alumni.

\section{Insert Table 1 here}

The response rate for current students was high with 275 (90\%) students fully completing the questionnaire. Of those responding, a greater proportion was female; most were aged between 20-24 years and; there was about an equal balance of full- and part-time students and of those employed or not employed (in all respects matching the full cohort of students). There was also approximately equal representation of students studying in Australia (Melbourne) and in other SE Asian campuses. 
The response rate for the alumni cohort was $25 \%$ with 111 graduates fully completing the questionnaire. Tests for differences between early and late respondents' did not reveal significant variations. Approximately two thirds of the respondents had completed their studies on a full-time basis and there were a slightly higher number of female respondents.

\section{Analysis and results}

To allow for reporting of potential variation in the characteristics of the two sample populations, analysis was undertaken and is reported separately for each group, i.e., students who were currently studying for an accounting qualification and alumni who had graduated in 2004 and 2005.

\subsection{Current students}

Nearly all students had joined, or intended to join, an accounting body. Of the sample respondents, 40 (15\%) were, or intended to be, a full member of Association of Chartered Certified Accountants (ACCA); 159 (58\%) were, or intended to be, a full member of CPA Australia (CPA); and 71 (26\%) were, or intended to be, a full member of the Institute of Chartered Accountants in Australia (ICAA) (Table 2). A few respondents joined or intended to join more than one professional body: $2 \%$ both ICAA and ACCA, $8 \%$ both ICAA and CPA Australia, 9\% both CPA Australia and ACCA. Notably, only two respondents were, or intended to be, full members of the National Institute of Accountants (NIA), a result which may potentially reflect the evolutionary development and competitive market positioning of the NIA in Australia at the time. Forty-two percent of current students had joined a professional accounting body as a provisional, affiliate or associate member.

\section{Insert Table 2 here}


To investigate the attributes that led respondents to their choice of professional accounting body, logit regressions were estimated for each of the membership choices: ACCA, ICAA and CPA Australia. The membership choices were not mutually exclusive (some respondents intended to join two or more bodies), so a single multinomial model was not appropriate. The sample numbers joining the other accounting bodies were not large enough for reliable modelling.

The potential explanatory attributes were initially a long list, with the attributes gender, age group, campus, mode of study, and whether employed or not, and the 13 importance attributes considered as potentially influencing their choice of professional body. The modelling followed a general to specific strategy, starting with all potentially explanatory attributes represented in the model and proceeding, step by step, to eliminate non-significant variables. In each modelling exercise, many attributes did not have a significant impact on the choice of professional accounting body and were dropped from the model; the final form of each model is reported below by professional body. In each of the models reported in Table 3, the gain in log-likelihood (reported below in each panel) is significant. The quasi-R-squared statistics and percentages correct predictions (also reported below in the relevant panels) show that the models provide a reasonable 'fit', although they also indicate room for other (not considered) factors that could also impact choice. The importance of the estimation lies in the short list of variables that are significant and in the longer list of variables that were found not to be significant (see discussion).

\subsubsection{ACCA}

The dependent variable in the logistic regression was coded 1 for those who joined (or intended to join) ACCA and 0 for all other accounting bodies. The most important attribute seen to have a significant impact on the decision to join ACCA is the campus attended (Wald 
statistic $=19.941, d f=3, p=0.000)$. Melbourne educated students are much less likely than students from the SE Asian campuses to join ACCA. The Odds ratio provides the clearest way to interpret the results: students from the Melbourne campus are one eighth as likely (0.125) to join ACCA than students from an Asian campus. Similarly, those employed were about one quarter as likely (0.259) to join ACCA than those not employed (see Table 3, Panel A).

\section{Insert Table 3 here}

\subsubsection{CPA Australia}

The dependent variable in the logistic regression was coded 1 for those who joined (or intended to join) CPA Australia and 0 for all other accounting bodies. The modelling for CPA Australia (see Table 3, Panel B) indicates some significant attributes in deciding to join CPA Australia (or not). The key findings are that full-time students are about one third (0.378) as likely to join CPA Australia as part-time students. Similarly, employed students are about one third (0.373) as likely as students not employed to join CPA Australia. Those who rate the cost of membership as an important attribute are more likely to join CPA Australia. Those concerned with permanent residency in Australia were also more likely to join CPA Australia.

\subsubsection{ICAA}

The dependent variable in the logistic regression was coded 1 for those who joined (or intended to join) ICAA and 0 for all other accounting bodies. The ICAA model is a stronger fit than the models for the other two bodies (see the fit statistics and percentage correct figures in Table 3, Panel C). Those students undertaking full-time study and employed have much greater odds (4.8 times than those in part-time study and 2.7 times than those not employed) of joining ICAA (and less of joining CPA Australia, as seen in the previous model). Campus attended overall was significant (Wald statistic $=11.884, d f=3, p=0.008$ ), although the 
individual effects of the campuses were not significant. The indication given in the data is that Melbourne students are more likely to join ICAA than the Asian campus students. Those concerned with permanent residency in Australia were less likely to join ICAA, and slightly more likely to join CPA Australia.

Overall, campus, full- or part-time study mode, employment and concern for permanent residency are seen to be the significant attributes in predicting the choice of professional accounting body. The campus impact accords with commonsense, with those from SE Asia more likely to join the more internationally orientated ACCA than Melbourne students, and the Melbourne students more likely to join the Australian body ICAA. CPA Australia falls between these two, indicating it has greater international recognition (in Singapore, Malaysia and Hong Kong) than ICAA, but less than ACCA.

Those employed already are more likely to join ICAA and less likely to join ACCA and CPA Australia. Similarly, full-time students were more likely to join ICAA and less likely to join ACCA and CPA Australia. CPA Australia was seen as more useful in helping with obtaining permanent residency (in Australia). The only instrumentalist feature of the bodies that had a significant impact on the choice was the cost to join - those for whom this was more important were more likely to join CPA Australia than the other professional bodies. This is consistent with the relatively lower joining fees of CPA Australia compared with the ICCA.

Career opportunities, international recognition and brand or reputation were reported to be important in the choice of professional body to join by the vast majority of respondents. Other attributes, such as potential/place of work and educational requirements also rated highly (Table 4).

\section{Insert Table 4 here}


The 13 importance attributes were all considered in the logit models reported earlier but found to be non-significant. This suggests that these attributes, while considered important, did not have a large impact on the choice of one professional body over another, that is, they are important but do not necessarily distinguish between professional accounting bodies.

\subsection{Alumni}

Of the 111 sample respondents, 50 (45\%) were, or intended to be, a full member of CPA Australia (CPA) and 47 (42\%) were, or intended to be, a full member of the ICCA. Interestingly, 10 respondents (10\%) had not joined nor intended to join a professional accounting body at the time of the survey (see Table 2). A few alumni joined two bodies: $4 \%$ joined both CPA Australia and ICAA, 2\% joined both the National Institute of Accountants (NIA) and CPA Australia and 2\% joined both NIA and ICAA - a majority of the small number joining NIA also joined one of the other main professional accounting bodies in Australia.

To investigate the attributes that led alumni to their choice of professional accounting body, logit regressions were estimated for each of these membership choices. The dependent variable took the value 1 for those who had joined the particular accounting body and 0 for the other accounting bodies. In Table 5, Panel C, the sample of alumni was limited to those who joined CPA Australia or ICAA ( $n=93$ ) with those choosing CPA Australia coded 1 (those in ICAA coded 0). The alumni sample was predominantly Melbourne-based and employed, so the campus and employed variables had insufficient variation to allow them to be meaningfully used in the modelling. Permanent residency is also not likely to be a concern for the vast majority of this sample and was unlikely to be a significant attribute in the choice of professional body. There were also too few who had joined ACCA and the NIA for that choice to be modelled. As in the current students' sample, many of the 13 importance attributes 
potentially influencing the choice of professional body were non-significant in the impact on choice and were removed from the model. The final form of each model is reported below.

\section{Insert Table 5 here}

The main finding is that those for whom membership benefits are more important are more likely to choose to join CPA Australia (Panel A). It is interesting to compare this result with the sample of final year students who selected CPA Australia where cost to join, rather than the benefits, was more instrumental in decision choice.

For those selecting the ICAA, the results suggest that if the cost of joining was more important to alumni, they were less likely to join ICAA (Panel B). Consistent with this finding, if it is important that the employer pays the membership costs, alumni are more likely to join the ICAA.

In considering the scores on importance, the notable point is that the pattern of scores from the alumni is very similar to that of the final year students. Generally, the alumni give lower scores for importance to the various attributes (Table 4), but the patterns of which attributes score relatively high or low is very consistent across the alumni and final year students.

As a further sensitivity check, we ran a logistic regression based on the sub-sample who opt for one, but not both, of ICAA or CPA Australia (see Table 5, Panel C). The drivers of choice between the two groups are: the more important the on-going cost of membership, the more likely CPA Australia will be chosen over ICAA, whilst the more important it is that the employer pays membership fees the more likely the ICAA will be chosen over CPA Australia.

\section{Discussion and conclusion}

In this study we sought to research the importance of a range of attributes for potential members in differentiating between professional accounting bodies (RQ1) and whether brand 
and reputation influenced the choice of a particular professional accounting body for potential members (RQ2). Our findings suggest that professional accounting bodies are perceived essentially as a collective profession of accountants which provide common attributes (features or benefits) of equal importance to potential and existing members of the profession. Confirming the general view within the literature on the accounting profession (see, for example, Velayutham and Rahman, 2000; Parker, 2005; Richardson and Jones, 2007), brand/reputation and the closely aligned attribute of international recognition of the professional body were common features of importance across all professional bodies identified by both the final-year students and alumni. Of note is the high level of importance afforded by both groups to career opportunities in the decision to join a professional accounting affiliation. We surmise that this perceived attribute or benefit of joining a professional accounting body may play a substantial antecedent or moderating role in the reputation of the professional accounting body and, more generally, in attracting and retaining members within the accounting profession.

Just as interesting as the commonality of importance attributes across professional bodies is the absence of age and gender as discriminatory attributes in the choice of affiliation of professional body. That is to say, no professional body is seen as particularly youth orientated or age-ist nor seen as more, or less, sexist. This is the view of those currently studying and alumni and is a finding which goes some way to providing much needed evidence regarding the impact (or lack thereof) of these market characteristics of age and gender as suggested by Simons et al. (2004).

Our finding of a "collective accounting profession", defined by its shared brand/reputation and international recognition, can be interpreted as significant for a profession seeking to competitively differentiate itself in the broader market for accounting services and as a measure of the marketing effectiveness of the professional bodies. This finding supports the view of Velayutham and Rahman (2000, p. 707) that leading accounting bodies in Australia 
and New Zealand have concluded "the major asset of the profession is the brand (qualification) that is recognised in the marketplace, and the principal objective of the accounting bodies is to enhance the image of this brand, thus providing better value to its members”.

The corollary of this interpretation, however, is that should professional accounting bodies such as the ICAA, CPA Australia and the ACCA wish to attain differentiated positions, then alternative strategies may be required. Marketing distinctive attributes (features or benefits) of value to (potential) members and/or modifying existing attributes of importance and/or developing strategies related to demographic attributes (see below) may offer greater potential for distinguishing between accounting bodies. This said, given the findings in this study of a very much undifferentiated accounting profession, we contemplate the rationale of professional accounting bodies investing further resources in pursuing different market positions rather than consolidating in the face of continuing social, political and economic environmental change. An inherent risk for professional accounting bodies in pursuing differentiated positions is the loss of a seemingly united profession in the eyes of current and potential members and increased exposure to competitive forces.

Despite the importance afforded by final-year students and alumni to information about brand/reputation, international recognition and educational requirements, our findings indicate these attributes did not translate into the decision of the choice of professional body. Attributes of study mode (full- or part-time), the campus (geographical location) at which students study and whether or not students are employed are the most significant attributes in distinguishing the (intended) choice of professional body for students who are currently studying. For professional accounting bodies seeking differentiation as a means of attracting and retaining members, this finding suggests that these market segment variables may provide more fruitful strategies. 
While not as significant as the decision attributes identified for current students, for new members of the professional bodies (alumni in this study), benefits of being a member are important for those joining CPA Australia while costs are an important attribute in the decision to join ICAA. The employer paying membership fees is also an important attribute in the decision to join ICAA and may be interpreted as implicitly stating the preference of the employer, i.e., if the employer has a strong preference for ICAA they are more likely to pay the fees whilst less likely to pay fees for CPA Australia. However, the less importance afforded to both the costs and salary associated with being an accountant and member of a professional accounting body relative to the importance of career opportunities (while not significant in the choice of professional body) may be interpreted as reflecting the long-term orientation of those electing to study accountancy and potentially explaining the lack of perceived differentiation between professional bodies. It is the outcome of potential career opportunities in the future and not the choice of professional body or costs that is the decision driver, i.e., it does not matter which professional body is selected as all provide the opportunity for employment. The attainment of the ACCA, CPA or CA designation or brand becomes the vehicle for the future career opportunities and for potentially attracting students to the accounting discipline.

A number of areas for further research develop from this current study. We did not take into account the potential impact of the various marketing campaigns of the professional accounting bodies in the period before and during the course of this study. The sample groups upon which the findings are founded reflect individuals who had chosen to study accountancy as a career at one particular university. These groups may not be representative of the general student and alumni population or of the population to which the professional bodies aim to market and differentiate themselves. Future studies might seek to gather student and alumni data from a range of universities and consider the nature, timing, medium and content of marketing by the professional accounting bodies. More extensive studies of stakeholders of the 
wider accounting profession such as current members of the profession, (potential) clients of professional accountants and the wider business community offers the opportunity to broaden our understanding of the perceptions of accounting brands.

A list of 13 importance attributes and five demographic attributes were included in the survey instrument and were developed from a variety of studies and from public information made available by professional accounting bodies. While provision was made for respondents to state other attributes of importance in influencing choice of professional body (with none being provided by respondents) there remains scope for extending and/or refining the number of attributes and monitoring shifts in the nature and sources of the information and its effects on brand differentiation and membership levels of professional accounting bodies. 


\section{Appendix 1}

Description of professional accounting bodies reported in the study

\section{Association of Chartered Certified Accountants (ACCA)}

The Association of Chartered Certified Accountants (ACCA) has 131,500 members and 362,000 student members in 170 countries. Their members known as Chartered Certified Accountants are employed in industry, public sector and public practice with over 60 percent in the corporate sector. With over 70 percent of their members and students based outside of the UK, ACCA aims to be the 'leading global professional accountancy body by reputation, influence and size' (ACCA, 2010). Depending on previous academic qualifications there are four entry points into the ACCA qualification; minimum entry requirements, mature student, graduate entry and access via a Certified Accounting Technician (CAT) qualification. In order to qualify for ACCA membership, an individual must complete 14 examinations (nine of which are eligible for exemptions depending on entry point), a minimum of three years relevant practical experience and a professional ethics module. For more information about ACCA see www.accaglobal.com.

\section{CPA Australia}

CPA Australia has over 122,000 members (of which approximately 60 percent are male) working in the areas of finance, accounting and business in more than 100 countries worldwide. On estimations, approximately 31 percent work in the public and corporate sectors, 21 percent in small and medium enterprises and 23 percent work outside Australia (CPA Australia, 2008). CPA Australia’s core services to members are 'education, training, technical support and advocacy’ (CPA Australia, 2010) and 'in the areas of financial reporting, taxation and corporate governance' CPA Australia is considered to be at the forefront in Australia and internationally (CPA Australia, 2010). To qualify to be a Certified Practising 
Accountant (CPA), members must hold a degree or postgraduate award recognised by CPA Australia and complete, within a six year period, the CPA professional level program including the practical experience component (CPA Australia, 2010). To maintain CPA status, members are required to complete 120 hours of continuing professional development every three years. For more information about CPA Australia see www.cpaaustralia.com.au.

\section{Institute of Chartered Accountants in Australia (ICAA)}

The Institute of Chartered Accountants in Australia (ICAA) represents over 50,000 chartered accountants (CAs) and 12,000 graduates enrolled in the CA program, working in industry and commerce, academia, government and public practice across 107 countries (ICCA, 2010). Known as chartered accountants they audit the majority of ASX listed companies. With the ICCA being an accredited higher education provider the completion of the CA program results in a postgraduate qualification (i.e. a graduate diploma of chartered accounting). The CA qualification is also a recognised 'approved qualification' for a CA wanting to register as an auditor in the United Kingdom (ICCA, 2010). To become a CA involves the completion of the graduate diploma of chartered accounting (or academic modules), which involves studying five modules (generally over a two year period), and three years work experience with an organisation recognised by the ICCA. Also during the program, students will be mentored by a CA. Graduates with a degree not in accounting can qualify for the CA program by completing a graduate conversion course, a graduate certificate of chartered accounting foundations or an entrance examination (ICCA, 2010). For more information about the ICAA see www.charteredaccountants.com.au. 


\section{National Institute of Accountants (NIA)}

The National Institute of Accountants (NIA) represents over '22,000 members and students working in industry, commerce, government, academia and private practice' (NIA, n.d.). The NIA is for accountants including bookkeepers 'recognised for their practical hands-on skills' and broad understanding of business and provides members with technical tools, information and advocacy' (NIA, n.d.). To obtain membership with the NIA, a prospective member must have a university degree in accounting and have completed three years of relevant industry experience or complete stage 1 of the NIA program if they hold an advanced diploma in accounting and have completed 3 years of relevant industry experience. Stage one of the NIA program involves the completion of a graduate certificate in professional accounting. Members can obtain professional national accountant (PNA) status through the completion of more stages of the NIA program and participating in the mentored experience program (NIA, n.d). For more information about the NIA see www.nia.org.au. 


\section{Appendix 2}

Survey instrument (extract*)

* Questions are not sequential

\section{Factors Influencing Choice of Professional Accounting Bodies}

We thank you for assisting us with this survey. All information is CONFIDENTIAL and no person will be identified.

The purpose of this research is to gather information about professional accounting bodies. This survey is printed on 6 pages and will take no longer than 10 minutes of your time to complete. Once completed please return via the reply-paid self addressed envelope provided. We thank you for your time.

\section{Section A}

3. Of which Professional Accounting Body are you (or do you intend to be) a full member? (please tick all relevant box/s)

Accounting Society of China (ASC)

Association of Chartered Certified Accountants (ACCA)

Chartered Institute of Management Accountants (CIMA)

Chinese Institute of Certified Public Accountants (CICPA)

CPA Australia

Hong Kong Institute of Certified Public Accountants (HKICPA)

Hong Kong Society of Accountants (HKSA)

Institute of Certified Public Accountants of Singapore (ICPAS)

Institute of Chartered Accountants Australia (ICAA)

Malaysian Institute of Accountants (MIA)

Malaysian Association of Certified Public Accountants (MACPA)

National Institute of Accountants Australia (NIA)

Other (Please specify):

Not planning to become a member of a professional accounting body

- Go to Section B on Page 6 

member (e.g., student member)? (please tick)

Yes

$\square$ No

8 How important to you are the following factors in influencing your choice of joining a particular professional accounting body? (please circle for each factor)

$$
1=\text { not important } \quad 5 \text { = very important }
$$

\begin{tabular}{|l|c|c|c|c|c|}
\hline Financial cost to join & 1 & 2 & 3 & 4 & 5 \\
\hline On-going membership costs & 1 & 2 & 3 & 4 & 5 \\
\hline $\begin{array}{l}\text { Professional education requirements } \\
\text { e.g., CPA program, CA program }\end{array}$ & 1 & 2 & 3 & 4 & 5 \\
\hline Reputation/Brand of the professional accounting body & 1 & 2 & 3 & 4 & 5 \\
\hline $\begin{array}{l}\text { Membership benefits } \\
\text { e.g., online library/research facilities, newsletters, continuing } \\
\text { professional development }\end{array}$ & 1 & 2 & 3 & 4 & 5 \\
\hline $\begin{array}{l}\text { Enhancing career opportunities } \\
\text { International recognition }\end{array}$ & 1 & 2 & 3 & 4 & 5 \\
\hline $\begin{array}{l}\text { Perceived expertise of the professional accounting body e.g., } \\
\text { associated with large public accounting focus versus broad industry } \\
\text { focus }\end{array}$ & 1 & 2 & 3 & 4 & 5 \\
\hline Salary of members of the accounting body & 1 & 2 & 3 & 4 & 5 \\
\hline Employer paying membership fees & 1 & 2 & 3 & 4 & 5 \\
\hline Potential/Place of work & 1 & 2 & 3 & 4 & 5 \\
\hline Ease of becoming a member: entry requirements & 1 & 2 & 3 & 4 & 5 \\
\hline Assisting in gaining permanent residency (PR) & 1 & 3 & 4 & 5 \\
\hline Other (Please specify): & 2 & 3 & 5 \\
\hline
\end{tabular}




\section{Section B}

Biographical Data (please tick the relevant box):

Gender:

$\square$ Male

Female

Age at 1st March 2006
$\square 20-24$
$\square 25-29$
$30-34$
$35-39$
$40+$

Please indicate in which mode of study you undertook or are undertaking your accounting degree (please tick the relevant box)
$\square$ Full Time
Part Time

Please indicate at which campus you undertook or are undertaking your accounting degree (please tick the relevant box)
Melbourne
$\square$ Hong Kong Management Association (HKMA)
$\square$ Metropolitan College (Malaysia)
Singapore Institute of Management (SIM)

Are you currently employed? $\square$ Yes $\quad \square$ No 


\section{References}

Albrecht, W. S. and R.J. Sack, 2000, Accounting education: Charting the course through a perilous future, Accounting Education Series 16, (American Accounting Association, Sarasota, Florida).

Association of Chartered Certified Accountants, About Us [Internet document] (Association of Chartered Certified Accountants, London) [created 2010; cited 9 February 2010], available from http://www.accaglobal.com

Birrell, B. and E. Healy, 2008, Migrant accountants - high numbers, poor outcomes, People and Place 16, 9-22.

Chen, C., K., T. Jones, and D. D. McIntyre, 2008, Analyzing the factors relevant to students' estimations of the benefits and costs of pursuing an accounting career, Accounting Education: An International Journal 17, 313-26.

CPA Australia, About CPA Australia [Internet document] (CPA Australia, Melbourne) [created 8 January 2010; cited 9 February 2010], available from http://www.cpaaustralia.com.au

CPA Australia, Our Members [Internet document] (CPA Australia, Melbourne) [created 12 December 2008; cited 9 February 2010], available from http://www.cpaaustralia.com.au

Day, G. S. and R. Wensley, 1988, Assessing advantage: A framework for diagnosing competitive superiority, Journal of Marketing 52, 1-20.

Felton, S. N., T. Dimnik, and M. Northey, 1995, A theory of reasoned action model of the chartered accountant career choice, Journal of Accounting Education 13, 1-19.

Forbis, J. L. and N. T. Mehta, 1981, Value-based strategies for industrial products, Business Horizons 24, 32-42. 
Institute of Chartered Accountants in Australia, About the Institute [Internet document] (Institute of Chartered Accountants in Australia, Sydney) [created 2010; cited 9 February 2010], available from http://www.charteredaccountants.com.au

Institute of Chartered Accountants in Australia and CPA Australia, Professional Accreditation Guidelines for Higher Education Programs [Internet document] (Institute of Chartered Accountants in Australia and CPA Australia, Melbourne) [created October 2009; cited 9 February 2010], available from http://www.cpaaustralia.com.au

Jackling, B., 2007, The lure of permanent residency and the aspirations and expectations of international students studying accounting in Australia, People and Place 15, 37-39.

Lancaster, K. J., 1966, A new approach to consumer theory, Journal of Political Economy 74, 132-157.

Lancaster, K. J., 1971, Consumer demand: A new approach (Columbia University Press, New York).

Mauldin, S., J. L. Crain, and P. H. Mounce, 2000, The accounting principles instructor's influence on students' decision to major in accounting, Journal of Education for Business Jan-Feb, 142-148.

National Institute of Accountants, NIA Home page [Internet document] (National Institute of Accountants, Melbourne) [cited 9 February 2010], available from http://www.nia.com.au

Paolillo, J. G. P. and R. W. Estes, 1982, An empirical analysis of career choice factors among accountants, attorneys, engineers and physicians, The Accounting Review LVII, 785793.

Parker, L. D., 2001, Back to the future: The broadening accounting trajectory, British Accounting Review 33, 421-453.

Parker, R. H., 2005, Naming and branding: Accountants and accountancy bodies in the British Empire and Commonwealth, 1853-2003, Accounting History 10, 7-46. 
Porter, M. E., 1985, Competitive advantage (The Free Press, New York).

Richardson, A. J. and D. G. B. Jones, 2007, Professional "brand", personal identity and resistance to change in the Canadian accounting profession: A comparative history of two accounting association merger negotiations, Accounting History 12, 135-164.

Richardson, A. J., 1997, Social closure in dynamic markets: The incomplete professional project in accountancy, Critical Perspectives on Accounting 8, 635-653.

Sauser, L. D., 2000, The CPA profession: Responding to a changing environment, S.A.M. Advanced Management Journal 65, 36- 40

Simons, K. A., D. R. Lowe, and D. E. Stout, 2004, Comprehensive literature review: Factors influencing choice of accounting as a major, Journal of the Academy of Business Education 5, 97-110.

Tan, L. M. and F. Laswad, 2006, Students' beliefs, attitudes and intentions to major in accounting, Accounting Education: An International Journal 15, 167-187.

Velayutham, S. and A. Rahman, 2000, Towards market differentiation in the accounting profession: The case of Australia and New Zealand, Critical Perspectives on Accounting 11, 691-711.

Velayutham, S., 1999/2000, The pacific accounting body in the $21^{\text {st }}$ century: The global franchise, Pacific Accounting Review 11, 163- 171. 
Table 1

Demographic attributes of the current students and alumni.

\begin{tabular}{ccc}
\hline & Current Students & Alumni \\
\cline { 2 - 3 } Gender: Male & & \\
Female & $35 \%$ & $42 \%$ \\
Age: $20-24$ & $65 \%$ & $58 \%$ \\
$25-29$ & $65 \%$ & $52 \%$ \\
$30-34$ & $19 \%$ & $22 \%$ \\
$35-39$ & $9 \%$ & $6 \%$ \\
$40+$ & $4 \%$ & $7 \%$ \\
Study Mode: Full Time & $3 \%$ & $13 \%$ \\
Part Time & $59 \%$ & \\
Employed: Yes & $41 \%$ & $68 \%$ \\
No & & $32 \%$ \\
Campus: Melbourne & $59 \%$ & $94 \%$ \\
Hong Kong & $41 \%$ & $6 \%$ \\
Malaysia & $54 \%$ & $99 \%$ \\
Singapore & $14 \%$ & $1 \%$ \\
Numbers of Respondents: & $15 \%$ & \\
& $17 \%$ & \\
\hline
\end{tabular}


Table 2

Professional body joined or intended to join

\begin{tabular}{|c|c|c|c|c|}
\hline \multirow[b]{2}{*}{$\begin{array}{l}\text { Professional Accounting } \\
\text { Body }\end{array}$} & \multicolumn{2}{|c|}{ Current Students } & \multicolumn{2}{|c|}{$\underline{\text { Alumni }}$} \\
\hline & $n=275$ & Percentage* & $\mathrm{n}=111$ & Percentage* \\
\hline CPA Australia (CPA) & 159 & 58 & 50 & 45 \\
\hline $\begin{array}{l}\text { Institute of Chartered } \\
\text { Accountants in Australia } \\
\text { (ICAA) }\end{array}$ & 71 & 26 & 47 & 42 \\
\hline $\begin{array}{l}\text { Association of Chartered } \\
\text { Certified Accountants } \\
\text { (ACCA) }\end{array}$ & 40 & 15 & 3 & 3 \\
\hline $\begin{array}{l}\text { Malaysian Institute of } \\
\text { Accountants (MIA) }\end{array}$ & 25 & 9 & 0 & 0 \\
\hline $\begin{array}{l}\text { Institute of Certified Public } \\
\text { Accountants of Singapore } \\
\text { (ICPAS) }\end{array}$ & 22 & 8 & 0 & 0 \\
\hline $\begin{array}{l}\text { Hong Kong Institute of } \\
\text { Certified Public Accountants } \\
\text { (HKICPA) }\end{array}$ & 16 & 6 & 0 & 0 \\
\hline $\begin{array}{l}\text { Accounting Society of China } \\
\text { (ASC) }\end{array}$ & 8 & 3 & 0 & 0 \\
\hline $\begin{array}{l}\text { Chartered Institute of } \\
\text { Management Accountants } \\
\text { (CIMA) }\end{array}$ & 8 & 3 & 0 & 0 \\
\hline $\begin{array}{l}\text { Chinese Institute of Certified } \\
\text { Public Accountants } \\
\text { (CICPA) }\end{array}$ & 8 & 3 & 0 & 0 \\
\hline $\begin{array}{l}\text { Malaysian Association of } \\
\text { Certified Public Accountants } \\
\text { (MACPA) }\end{array}$ & 8 & 3 & 0 & 0 \\
\hline $\begin{array}{l}\text { National Institute of } \\
\text { Accountants Australia (NIA) }\end{array}$ & 5 & 2 & 7 & 6 \\
\hline $\begin{array}{l}\text { Hong Kong Society of } \\
\text { Accountants (HKSA) }\end{array}$ & 3 & 1 & 0 & 0 \\
\hline Other & 11 & 4 & 1 & 1 \\
\hline None & 22 & 8 & 11 & 10 \\
\hline
\end{tabular}

* The percentage total is greater than 100 due to respondents joining one or more bodies 
Table 3

Results of the attributes influencing the choice of professional accounting bodies for current students

Panel A: Association of Chartered Certified Accountants (ACCA)

\begin{tabular}{lllcl}
\hline Variable (attribute) & coefficient & Odds ratio & Wald & p-value \\
\hline Constant & 0.068 & & 0.026 & 0.873 \\
Campus & & & 19.941 & 0.000 \\
$\quad$ Melbourne & -2.077 & 0.125 & 18.609 & 0.000 \\
$\quad$ Hong Kong & -0.172 & 0.842 & 0.091 & 0.842 \\
$\quad$ Malaysia & -1.429 & 0.239 & 6.242 & 0.239 \\
Employed & -1.351 & 0.259 & 8.169 & 0.004 \\
\hline
\end{tabular}

$2 *$ [change in Log Likelihood over constants only model] $=27.963$ with 4 df Chi-square pvalue $=0.000$

Cox and Snell R-squared $=0.097$, Nagelkerke R-squared $=0.172$.

The overall percentage of responses correctly predicted is $86 \%$ (but only $20 \%$ of ACCA memberships correctly predicted).

Panel B: CPA Australia

\begin{tabular}{lclll}
\hline Variable (attribute) & coefficient & Odds ratio & Wald & p-value \\
\hline Constant & 0.245 & & 0.153 & 0.696 \\
Study mode & -0.974 & 0.378 & 8.490 & 0.004 \\
Employed & -0.987 & 0.373 & 8.555 & 0.003 \\
Cost to join & 0.347 & 1.415 & 7.587 & 0.006 \\
Permanent residency & 0.171 & 1.187 & 2.608 & 0.106 \\
\hline
\end{tabular}

$2 *$ [change in Log Likelihood over constants only model] $=34.175$ with $4 \mathrm{df}$ Chi-square pvalue $=0.000$

Cox and Snell R-squared $=0.126$, Nagelkerke R-squared $=0.172$.

The overall percentage of responses correctly predicted is $72 \%$ (89\% of CPA Australia memberships correctly predicted and $43 \%$ success in predicting non-CPA joiners).

\begin{tabular}{lcccc}
\hline \multicolumn{5}{l}{ Panel C: Institute of Chartered Accountants in Australia (ICAA) } \\
\hline Variable (attribute) & coefficient & Odds ratio & Wald & p-value \\
\hline Constant & -2.611 & & 11.175 & 0.001 \\
Campus & & & 11.884 & 0.008 \\
$\quad$ Melbourne & 1.264 & 3.540 & 2.925 & 0.087 \\
$\quad$ Hong Kong & -73.701 & 0.000 & 0.000 & 1.000 \\
$\quad$ Malaysia & -0.719 & 0.487 & 0.544 & 0.487 \\
Employed & 1.009 & 2.742 & 6.270 & 0.012 \\
Study mode & 1.578 & 4.846 & 9.991 & 0.002 \\
Permanent residency & -0.308 & 0.735 & 5.390 & 0.020
\end{tabular}

$2 *$ [change in Log Likelihood over constants only model] $=89.037$ with 6 df Chi-sq p-value $=$ 0.000

Cox and Snell R-squared $=0.290$, Nagelkerke R-squared $=0.418$.

The overall percentage of responses correctly predicted is $81 \%$ (55\% of ICAA memberships correctly predicted, $91 \%$ success in predicting non-ICAA joiners). 
Table 4

Importance of various attribute in influencing the choice of professional accounting bodies (scale $1=$ not important to 5 = very important)

\begin{tabular}{lcc}
\hline Attribute & $\begin{array}{c}\text { Current Students } \\
\text { Percentage rating } \\
\text { attribute as } \\
\text { important or very } \\
\text { important }\end{array}$ & $\begin{array}{c}\text { Alumni } \\
\text { Percentage rating } \\
\text { attribute as } \\
\text { important or very } \\
\text { important }\end{array}$ \\
\hline Career opportunities & 93 & 85 \\
International recognition & 86 & 73 \\
Brand or reputation & 85 & 86 \\
Place of work & 75 & 70 \\
Educational requirements & 73 & 70 \\
Salary of members of the accounting body & 67 & 60 \\
Perceived expertise of the accounting bodies & 66 & 68 \\
Ease of becoming a member & 56 & 36 \\
Membership benefits & 49 & 57 \\
Employer pays membership fees & 46 & 45 \\
Ongoing membership cost & 34 & 35 \\
Cost to join & 34 & 34 \\
Permanent residency & 28 & 12 \\
\hline
\end{tabular}


Table 5

Results of the attributes influencing the choice of professional accounting bodies for alumni

Panel A: CPA Australia

\begin{tabular}{lllll}
\hline Variable (attribute) & coefficient & Odds ratio & Wald & p-value \\
\hline Constant & -1.636 & & 6.535 & 0.011 \\
Membership benefits & 0.517 & 1.677 & 7.338 & 0.007 \\
\hline
\end{tabular}

$2 *$ [change in Log Likelihood over constants only model] $=8.025$ with $1 \mathrm{df}$ Chi-square p-value $=0.005$

Cox and Snell R-squared $=0.077$, Nagelkerke R-squared $=0.103$.

Overall percentage of responses correctly predicted $=67 \%$ (58\% of CPA Australia memberships correctly predicted, and 76\% success in predicting non-CPA joiners)

Panel B: Institute of Chartered Accountants in Australia (ICAA)

\begin{tabular}{lllll}
\hline Variable (attribute) & coefficient & Odds ratio & Wald & p-value \\
\hline Constant & -0.186 & & 0.100 & 0.752 \\
Cost of joining & -0.580 & 0.560 & 9.458 & 0.002 \\
Employer pays & 0.508 & 1.661 & 7.903 & 0.005 \\
\hline
\end{tabular}

$2 *$ [change in Log Likelihood over constants only model] $=14.816$ with $2 \mathrm{df}$ Chi-square pvalue $=0.001$.

Cox and Snell R-squared $=0.138$, Nagelkerke R-squared $=0.184$.

Percent of responses correctly predicted $=66 \%(60 \%$ of ICAA memberships correctly predicted, $72 \%$ success in predicting non-ICAA joiners).

Panel C: CPA Australia v Institute of Chartered Accountants in Australia (ICAA)

\begin{tabular}{lllll}
\hline Variable (attribute) & coefficient & Odds ratio & Wald & p-value \\
\hline Constant & -0.049 & & 0.006 & 0.937 \\
Cost of joining & 0.660 & 1.936 & 10.252 & 0.001 \\
Employer pays & -0.501 & 0.606 & 7.661 & 0.008 \\
\hline
\end{tabular}

$2 *$ [change in Log Likelihood over constants only model] $=15.386$ with 2 df Chi-square pvalue $=0.0005$.

Percent of responses correctly predicted $=58 \%$ (61\% of CPA Australia memberships correctly predicted and 55\% of ICAA memberships correctly predicted). 